gathering of experts is expected. A graph on the pamphlet shows how rapid has been the growth in popularity of this undertaking since the first 'Achema' was held at Hannover in 1920. Admission cards will be issued free on application to the Management, Dechema-Gesellschäftsstelle, Seelze bei Hannover. Two international postage stamps should be enclosed. A handbook containing fuller particulars will be issued shortly. Arrangements are being made by Messrs. Hagemann and Co., Travel-bureau, Bad Aachen, Bahnhofstrasse, 32, for the issue of cheap excursion fares from England and other countries.

\section{Universal Decimal Classification in Germany}

The past three years have witnessed in Germany a rapid development of interest in the universal decimal classification, the most important manifestation of which has been the adoption of that system by the Deutscher Normenausschuss for codifying its published standards. The need for a German edition of the classification has been felt, and is now to be met. The production of a new (third) edition of the classification will take place in the next three years, 193436 , under the auspices of the Normenausschuss and the Ministry of the Interior. The work has the official approval of the Institut International de Documentation and will incorporate all the considerable amendments and additions made to the second French edition 1927-29 since publication of the latter. The additions will total some 10,000 classes, mainly in science and technology, bringing the total number of classes to approximately 70,000. The work will be published in ten quarterly parts, of standard format $A 4$ and comprising about 160 pages. The first part will appear in April of this year, and the cost of each part will be 11 gold marks if ordered before March 1 ; afterwards 12.50 gold marks. Messrs. Beuth-Verlag, G.M.B.H., Berlin, S.W.19, are the publishers.

\section{The Night-Sky in March}

THE only striking planetary object in the March sky is Jupiter, which can be seen in the eastern sky before midnight close to the star $\alpha$ Virginis (Spica), and the two form a conspicuous pair. There will be an occultation by the moon of the star $\alpha$ Scorpii (Antares) on March 8, but the phenomenon will not be visible at Greenwich (it will be visible at the Cape of Good Hope). On March 26 the moon will occult $\delta$ Cancri, the magnitude of which is $4 \cdot 2$. This occultation will be visible at Greenwich and will take place early in the morning (at 3h.02m.G.M.T.). At this hour the phenomenon will scarcely tempt any save regular observers of occultations, especially as we can warn our readers of two occultations which will occur later in the year of bright stars both of which will occur before midnight.

\section{Announcements}

THE newly formed Microchemical Club will hold its first scientific meeting on Saturday, March 17, at $10.30 \mathrm{a} . \mathrm{m}$. at the Lister Institute, Chelsea Bridge Road, London. At 2.30 p.m. on the same day and at the same place, the first annual general meeting will be held to elect officers, adopt a constitution and transact other business. Communications on microchemical subjects are invited; they may deal with applications and development of micro methods in any branch of science. Communications ean be sent to S. J. Folley, National Institute for Research in Dairying, Shinfield, Nr. Reading.

THe prize for 1933 of $£ 100$ awarded by the Thomas Gray Memorial Trust of the Royal Society of Arts for an essay in connexion with fire in a modern passenger vessel or in a cargo vessel at sea, in port or in a builder's yard has been awarded to Commander R. D. Binney. The prize of $£ 100$ for an improvement in the science or practice of navigation has been awarded to Dr. A. B. Wood, F. D. Smith and J. A. McGeachy, Admiralty Research Laboratory, Tedding ton, for their silent magneto-striction echo sounder with recorder. The prizes for 1934 are being offered for an invention, publication, diagram, etc., which is considered to be an advancement in the science or practice of navigation and for an essay on a navigation topic. Essays or proofs of claim must be submitted before December 31. Titles of the essay and other information can be obtained from the Secretary, Royal Society of Arts, John Street, Adelphi, London, W.C.2.

IN an article on "Industrial Research" in Nature of January 20 , it is stated on p. 80 that the contribution of electric supply authorities in Great Britain to the British Electrical and Allied Industries Research Association is about $£ 5,000$. We are informed by the Association that its income from this source in 1933 was $£ 15,000$.

Applications are invited for the following appointments, on or before the dates mentioned :-A probationary assistant engineer (male) in the Post Office Engineering Department-The Secretary, Civil Service Commission, Burlington Gardens, London, W.1 (March 8). A senior library assistant to the Hertfordshire County Council-The Clerk to the County Council, 28, Castle Street, Hertford (March 10). A head of the Mechanical and Civil Engineering Department of the Technical College, SunderlandChief Education Officer, Education Offices, 15, John Street, Sunderland (March 12). A University professor of anatomy at St. Thomas's Hospital Medical School-The Academic Registrar, University of London, S.W.7 (May 16). A director of food investigation in the Department of Scientific and Industrial Research-The Secretary, 16, Old Queen Street, Westminster, S.W.1 (March 17). A head mistress of the Day Trade School for Girls, Wavertree Technical Institute--The Director of Education, 14, Sir Thomas Street, Liverpool (March 17). A professor of mathe. matics at the Royal Technical College, Glasgow-The Secretary (March 26). A staff lecturer and demonstrator in botany, and a demonstrator and assistant lecturer in chemistry at the Royal Holloway College, Englefield Green, Surrey-The Principal (April 14). A signal engineer for the Way and Works Department, Government Railway, Ceylon-Crown Agents for the Colonies, 4, Millbank, London, S.W.1. 